\title{
Wojciech Cwalina i Bruce Newman o nowych mediach w komunikacji politycznej
}

\section{Z Wojciechem Cwaliną i Bruce'em Newmanem rozmawia Barbara Brodzińska-Mirowska}

\begin{abstract}
owe media - ich wpływ na komunikację polityczną stanowi obszar cieszący się dużym zainteresowaniem badaczy. Dynamiczne zmiany kontaktów polityków z wyborcami, wynikające np. z rozwoju Internetu, rodzą wiele pytań, prowadzone zaś systematycznie badania pozwolą na opisanie specyfiki komunikacji politycznej w XXI wieku. Social media odgrywają coraz większą rolę w komunikacji politycznej. W jaki sposób mogą zmienić i wzbogacić relacje między politykami i ich wyborcami? Między innymi o to zapytaliśmy dwóch uznanych ekspertów z zakresu marketingu politycznego - prof. Bruce'a Newmana z Katedry Marketingu z DePaul University w Chicago oraz dr. hab. Wojciecha Cwalinę ze Szkoły Wyższej Psychologii Społecznej w Warszawie.
\end{abstract}

\section{Rozmowa z Wojciechem Cwaliną}

\section{Co zyskuje marketing polityczny dzięki nowym mediom?}

Dzięki nowym mediom marketing polityczny zyskuje kolejny obiecujący kanał komunikacji z obywatelami - w tym także z wyborcami. Dają one możliwość „ominięcia” tradycyjnych mediów elektronicznych (zwłaszcza telewizji) i drukowanych. Tym samym polityk/kandydat może kształtować i kierować swój przekaz według własnej wizji. Nowe media są sposobem dotarcia do grup wyborców, którzy polityką interesują się stosunkowo mało, którzy polegają na opiniach znajomych czy "przyjaciół”. Dzięki nowym mediom mogą oni znaleźć podobnych sobie i przyłączyć się do gru- 
py ludzi zaangażowanych na rzecz określonego kandydata. I - co warto podkreślić - w znacznej części jest to praca offline. Nowe media pozwalają też na lepsze poznanie potrzeb wyborców. Wręcz zaczyna się już wydzielać wśród działań marketingowych tzw. kampanie hipermedialne, oparte na monitorowaniu działań w sieci podejmowanych przez poszczególne osoby opisane przez IP.

\section{Czy Pana zdaniem social media mogą wpłynąć na poprawę wizerun- ku polityków i polityki? Czy dają szansę na bardziej pozytywne nasta- wienie społeczeństwa do polityki?}

Media społecznościowe z pewnością mogą wpłynąć na poprawę wizerunku zarówno polityki, jak i polityków. Przy czym wyrażenie "mogą” jest jedynie pewną potencjalnością. Z perspektywy marketingowej media te są kolejnym „narzędziem", które znajduje się w repertuarze działań mających na celu zdobycie poparcia wyborców. Zatem to, czy i jakie zmiany mogą pojawić się w odbiorze polityki przez społeczeństwo, zależy przede wszystkim od polityków, którzy będą z nich korzystać. Jeśli ich głównym, a często jedynym, celem będzie zwycięstwo wyborcze czy znalezienie się w parlamencie - to raczej nie ma szans na to, że media społecznościowe coś zmienią lub poprawią. Jeśli natomiast będą one wykorzystywane do rzeczywistej komunikacji z wyborcami czy szerzej - z obywatelami, jeśli będą umożliwiać budowanie wzajemnego zaufania, opartego na dotrzymywaniu obietnic przez obie strony, jeśli sprawią, że obywatele chętniej zaczną poszukiwać informacji politycznych - wówczas jest szansa, że ten sposób komunikacji będzie mógł coś zmienić. Dużo jest tu jednak „ıjeśli". Wynika to $z$ tego, że "uprawianie polityki" i „służba obywatelom" często w Polsce stanowią odrębne wymiary.

\section{W jaki sposób politycy mogą wykorzystać nowe media i social media w budowaniu swojego wizerunku?}

Przede wszystkim nowe media dają możliwość politykom bezpośredniego komunikowania się z wyborcami z ominięciem tradycyjnych mediów. Jest to, w pewnym sensie, powrót do bezpośredniej komunikacji między politykami a wyborcami. Przy czym, jeśli dawniej spotkanie się obu stron było czymś wyjątkowym i stosunkowo rzadkim, to dzięki Internetowi i mediom społecznościowym - jest to kontakt znacznie częstszy. Tym samym kandydaci mają możliwość budowania swojego wizerunku poza soczewką dziennikarzy i mediów. Mają szansę być bardziej naturalni - oczywi- 
ście, nie wszyscy politycy tego chcą i z tego byliby zadowoleni. Przedstawić siebie jako „człowieka”, a nie „supermana”. Czyli kogoś, kto ma swoje upodobania, słabości, ale i mocne strony. Nowe media dają duże możliwości w budowaniu wzajemnego zaufania między politykami a wyborcami: umożliwiają lepsze poznanie się, polubienie i podejmowanie wspólnych wyzwań. Lecz nowe media dają również szerszy wgląd w osobowość i działania kandydata, a tym samym - trudniej jest to zaufanie podtrzymać. Zwłaszcza jeśli było ono w zamyśle polityka jedynie „sztuczką".

\section{Gdyby miał Pan wskazać przełomowy dla komunikowania politycz- nego moment w historii, to na co zwróciłby Pan uwagę?}

Według mnie jest kilka takich przełomowych momentów. Po pierwsze, wykorzystanie samolotów przy przemieszczaniu się po kraju ze spotkania wyborczego na spotkanie przez Adolfa Hitlera podczas wyborów w 1932 roku. Po drugie, Rozmowy przy kominku - radiowe audycje/wystąpienia Franklina D. Roosevelta zapoczątkowane w 1933 roku. Po trzecie, pierwsza telewizyjna reklama polityczna wyemitowana przez sztab wyborczy Dwighta D. Eisenhowera podczas kampanii prezydenckiej w 1952 roku oraz "kultowa” reklama lękowa/negatywna - Dausy Girl, wyprodukowana dla Lyndona Johnsona przez Tony'ego Schwartza na potrzeby kampanii prezydenckiej w 1964 roku. Po czwarte, posłużenie się głębokimi badaniami marketingowymi oraz wprowadzenie segmentacji rynku wyborczego przez sztab Richarda Nixona podczas kampanii prezydenckiej w 1968 roku. Po piąte, włączenie direct mail jako standardowego sposobu komunikacji z wyborcami i pozyskiwania funduszy w latach 70. Po szóste, pierwsza strona internetowa kandydata politycznego (Dianne Feinstein, senator z Kalifornii) przygotowana specjalnie na potrzeby kampanii wyborczej w 1994 roku. Po siódme, pierwszy blog kandydata na prezydenta - Howarda Deana w kampanii z 2004 roku. Po ósme, rok 2008 i wykorzystanie portali społecznościowych przez Baracka Obamę.

\section{Jakie wyzwania stoją przed marketingiem politycznym w dobie roz- woju dziennikarstwa obywatelskiego?}

Wydaje się, że wyzwaniem dla marketingu politycznego będzie „włączenie" swoich przekazów w te będące przedmiotem dziennikarstwa obywatelskiego. To znaczy bardziej subtelne metody tworzenia „opowieści”, które będą ciekawe i warte podchwycenia i powielenia. Czyli, w pewnym sensie, odejście od dbania o propozycje programowe formułowane 
często w sposób mglisty i mało wiarygodny na rzecz narracji, przedstawiania własnej „lekkiej” wizji. Wizji, która będzie zrozumiała dla obywateli i która będzie rezonowała $z$ ich codziennymi problemami i zainteresowaniami.

\section{Rozmowa z Bruce'em Newmanem}

What does the political marketing gain thanks to the new media? It gains an interactive component that allows the media to give and get immediate responses, as well as citizens among one another. There is a spontaneity that didn't exist before, making people more like to communicate among one another.

Can the social media influence the improvement of the image of politicians and in general of the politics? Do they give a chance for a morepositive attitude of a society towards politics?

Social media only serves as a tool for those who want to use it, making it possible to both improve and hurt the image of politician or political party. It just means that the tool is available for more people to use to impact on an image. It is positive in the sense that it gets more people involved in the political process but can be easily abused by people whose mission is to destroy and knock down, as well as support and build stronger.

In what way can the politicians use the new media and the social media in building own's image?

By reinforcing an image on a more regular and consistent basis; by serving as a tool to invite more people to participate in the political process; by highlighting the positive aspects of ones own image and reinforcing the negative aspects of a competitor.

If you were to indicate the crucial moments in history relating to political communication, on what would you focus your attention? Use of radio in the US in 1950s by president Dwight Eisenhower; Use of TV in 1960 in the televised debate between Richard Nixon and John Kennedy; use of mass media as a propaganda tool by Richard Nixon in 1968; use of marketing research to shape messages by pollster Pat Cadell for Jimmy Carter in 1976, use of imagery by Ronald Reagan through television 
in 1984 and1988, use of technology in the war room by the Clinton White House in 1992; use of social media by Barack Obama in 2008.

What challenges does the political marketing face in the time of the development of civic journalism?

The need to respond to a critical review of politicians and political parties by respected journalists like yourself. With social media this challenge becomes greater because of the immense number of increased outlets, but at the same time, becomes easier because of the ability of politicians to reach out to people through more unorthodox outlets. 